\title{
Öz-düzenleyici Öğrenme Stratejileri, Epistemolojik İnançlar ve Akademik Benlik Kavramı ile Matematik Başarısı Arasındaki İlişsii ${ }^{1}$
}

\author{
Zeynep Dursun Sürmeli ${ }^{2}$ ve Gülsen Ünver ${ }^{3}$
}

Makale geçmişi

Makale geliş tarihi: 2 Nisan 2016

Yayına kabul tarihi: 6 Aralık 2016

Çevrimiçi yayın tarihi: 16 Mart 2017

Öz: Bu araştırmada, dokuzuncu sınıf öğrencilerinin öz-düzenleyici öğrenme stratejileri, epistemolojik inançları ve akademik benlik kavramları ile matematik başarısı arasındaki ilişki incelenmiştir. Araştırma, 2013-2014 eğitim öğretim yılında İstanbul Avrupa yakasında bulunan ortaöğretim kurumlarından seçkisiz küme örnekleme yöntemiyle seçilen liselerde öğrenim gören 630 dokuzuncu sınıf öğrencisi üzerinde yürütülmüştür. İlişkisel tarama türünde olan araştırmada öğrencilerin öz-düzenleyici öğrenme stratejilerini ölçmek için “Öğrenmeye İlişkin Motivasyonel Stratejiler Ölçeği”' nde yer alan 'Öz-düzenleme' ve 'Bilişsel Strateji Kullanımı' alt ölçekleri, öğrencilerin epistemolojik inançlarını ölçmek için "Matematik Odaklı Epistemolojik İnançlar Ölçeği”" ve öğrencilerin akademik benlik kavramını ölçmek için "Akademik Benlik Kavramı Ölçeği” kullanılmıştır. Öğrencilerin matematik başarısı ise, matematik başarı testinden aldıkları puan ile ölçülmüştür. Araştırmanın amacı doğrultusunda yordayıcı değişkenlerin yordanan değişken ile ilişkisi korelasyon ve çoklu regresyon analiz teknikleri kullanılarak incelenmiştir. Araştırma bulguları, bilişsel strateji kullanımı ve akademik benlik kavramı ile matematik başarısı arasında istatistiksel olarak anlamlı bir ilişki olduğunu ortaya koymaktadır. Öz-düzenleme ve epistemolojik inançlar ile matematik başarısı arasında istatistiksel olarak anlamlı bir ilişki olmadığı görülmüştür. Araştırma sonucunda, matematik başarısının akademik benlik kavramı değişkeni tarafından anlamlı düzeyde yordandığg $(\% 10)$ görülmüştür. Öz-düzenleyici öğrenme stratejileri ve epistemolojik inançlar değişkenlerinin ise matematik başarısını anlamlı düzeyde yordamadığı ortaya çıkmıştır.

Anahtar Kelimeler: Öz-düzenleyici öğrenme stratejileri, epistemolojik inançlar, akademik benlik kavramı, matematik başarısı

DOI: $10.16949 /$ turkbilmat.298393

\begin{abstract}
In this study, the correlation between math achievement and self-regulating learning strategies, epistemological beliefs, academic self-concept of $9^{\text {th }}$ grade student was examined. In 2013-2014 academic year, the study was performed on 630 students of $9^{\text {th }}$ grade that receive education in high schools chosen from the institution of secondary education in European side of İstanbul through random cluster sampling. In study of correlational survey model, the sub-scales of "Self-regulation" and "The Cognitive Strategy Use", as "The Motivated Strategies for Learning Questionnaire", was used. The epistemological beliefs of students were evaluated through "The Mathematics-Oriented Epistemological Beliefs Scale". To evaluate the academic selfconcept of students, "Academics Self-concepts Scale" was used. The math achievement of the students was evaluated by grade that they obtained from math achievement test. In the direction of the study purpose, the relation between regressive variables and regressing variables was examined by regression analysis techniques. The result of this study proved that there was statistically a meaningful correlation between the use of cognitive strategy, academics self-concept and the math achievement. In addition, it was shown that the math achievement was not present any statistical meaningful correlation with self-regulation and epistemological beliefs. In the result of this study, it was shown that the math achievement was significantly predicted (10\%) by the variable of academics self-concept whereas it was not significantly predicted by variables of self-regulating learning strategies and epistemological beliefs.
\end{abstract}

Keywords: Self-regulating learning strategy, epistemological beliefs, academics self-concept, the math achievement

See Extended Abstract

\footnotetext{
${ }^{1}$ Bu çalışma birinci yazarın ikinci yazar danışmanlığında yaptığı “ Öz-düzenleyici Öğrenme Stratejileri, Epistemolojik İnançlar ve Akademik Benlik Kavramı ile Matematik Başarısı Arasındaki İlişki” başlıklı yüksek lisans tezinden üretilmiştir.

${ }^{2}$ Matematik Öğretmeni, Milli Eğitim Bakanlığı, Türkiye, zeynepdsy@gmail.com

${ }^{3}$ Doç. Dr., Ege Üniversitesi, Eğitim Fakültesi, Eğitim Bilimleri Bölümü, Türkiye, gulsen.unver@ege.edu.tr
} 


\section{Giriş}

Matematik, bilimde ve günlük hayatta karşılaştığımız problemlerin çözümünde kullandığımız önemli araçlardan biridir (Baykul, 2000). Matematiği anlayabilen, günlük yaşamında matematik bilgisini ve matematiksel becerileri kullanabilen insan ihtiyac1 giderek artmaktadır. Eğitimin her kademesinde matematik ile ilgili kazanımlara yer verilmiştir. Matematik, insanlar tarafından iyi bir yaşamın ve iyi bir kariyerin kapısını açıcı anahtar olarak görülmektedir (Stafslien, 2001). Aynı zamanda matematik, hayatın ve evrenin anlaşılması ve bunlar hakkında fikirler üretilebilmesi için yardımcı bir eleman olarak da görülmektedir (Ernest, 1991). Bu nedenle, günümüzde eğitimle ilgili yapılan reform çalışmalarının en önemli amaçlarından biri, ögrencilerin matematiği anlayarak öğrenmelerine yardımcı olabilecek bir sistemin oluşturulmasını sağlamaktır (Franke \& Kazemi, 2001). Öğretimine her zaman büyük bir önem ve ağırlık verilen bir ders olmasına rağmen, matematik hala pek çok öğrenci tarafindan anlaşılması ve öğrenilmesi güç bir ders olarak algılanmaktadır. Hatta matematik, öğrencilerin çoğu için bir bulmaca işlemi olarak algılanmaktadır (Gray \& Tall, 1992). Öğrencilerin çoğunun, matematiğe karşı bu şekilde olumsuz gözle bakmalarını etkileyen birçok faktör vardır. Öğrencilerin matematik dersindeki başarılarını etkileyen faktörlerin araştırılması, matematik becerilerinin geliştirilmesine yardımcı olabilir. Matematik becerilerini geliştirmek, günlük hayatta kişinin karşılaşacağı pek çok problemi daha sistematik bir şekilde çözmesini sağlayabilir (Yenilmez ve Duman, 2008). Matematik başarısını ölçmek üzere yapılan uluslararası sınavlar ile ulusal düzeyde yapılan merkezi sınavların sonuçları eğitimciler için yol göstericidir. 2012 yılında yapılan Yükseköğretime Giriş Sınavı'nda (YGS), sınava katılan 1 milyon 837 bin 344 adayın yaklaşık 700 bini matematikten sıfır almıştır (Emiroğlu, 2012). 2012 yılında yapılan YGS sınavının 40 soruluk temel matematik testi ortalaması 6,92 ve 2015 yılındaki ortalama 5,2 dir (Öğrenci Seçme ve Yerleştirme Merkezi [ÖSYM], 2012, 2015). Bu veriler ile Ekonomik İşbirliği ve Kalkınma Örgütü'nün (OECD) Uluslararası Öğrenci Değerlendirme Programı (PISA) raporları birbirini destekler niteliktedir. 2012 yılında matematik alanında gerçekleştirilen, 65 ülkenin katıldığı sınavda ülkemiz matematik başarı sıralamasında 44. sırada yer almıştır. 2012 yılı sonuçlarına bakıldığında ülkemizin matematik ortalamasında OECD ortalamasının altında kaldığı görülmektedir (Milli Eğitim Bakanlığı [MEB], 2013). Bu durum matematikte başarısızlığın nedenlerinin araştırılması gerektiğini ortaya çıkarmıştır. Bu nedenle ulusal ve uluslararası düzeyde öğrencilerin seçilmesi, yerleştirilmesi ve birçok eğitim kurumuna öğrenci kabulünde önemli bir yere sahip olan matematik başarısını kuramsal olarak yordayan bazı değişkenlerin araştırılmasına gereksinim duyulmuştur. 2015 yılı PISA sonuçlarına göre 64 ülkenin katıldığı sınavda ülkemiz matematik başarı sıralamasında 45. sırada yer almıştır. 2012 ve 2015 yılı sonuçları karşılaştırıldığında ülkemizin matematik başarı sıralamasında gerilediği görülmektedir (Kocabaş, 2016). Bu durum matematik başarısına etki eden değişkenlerin araştırılmasının gerekliliğini vurgulamaktadır. 
Matematik başarısı ile duyuşsal ve bilişsel değişkenler arasındaki ilişkiyi inceleyen ve araştıran birçok araştırma yapılmıştır (Anderson ve ark., 2006; Nasser \& Birenbaum, 2004). Alanyazın incelendiğinde ön bilgi, yetenek, motivasyonel ve duyuşsal değişkenlerin matematik başarısına etki ettiği görülmektedir. Çeşitli araştırmalar öğrencilerin başarı ile ilgili yaşadığı sıkıntılarının çoğunun duyuşsal olduğunu göstermektedir (Mcleod, 1992; Richardson \& Suinn, 1972). Suinn ve Edwards (1982), matematik başarısındaki varyansın neredeyse yarısının zihinsel faktörler dışındaki faktörlerle açıklandığını söylemektedir. Bloom'un tam öğrenme modelinde yer alan duyuşsal giriş özelliklerinin (ilgi, tutum, akademik benlik), başarıdaki değişkenliğin \%25'ini açıklama gücünde olduğu ifade edilmektedir (Senemoğlu, 2010). Öğrencilerin tutumları, kaygıları, inançları, kendilerine güvenleri gibi duyuşsal özellikler, matematik performanslarında önemli bir yere sahiptir (Mcleod, 1992).

Başarı ve akademik performansa etki ettiği düşünülen değişkenlerden biri özdüzenleyici öğrenmedir (Boekaerts, 1996). Öz-düzenleyici öğrenme, bireyin davranışlarını gözleyip, ölçütleriyle karşılaştırarak yargıda bulunması ve gerekiyorsa davranışlarını ölçütlerine uygun hale getirmesidir (Bandura, 1997). Başarısızlığa neden olan etkenleri araştıran çalışmalar sonucunda başarıları düşük öğrencilerin özyeterlik algılarının düşük olduğu (Ader, 2004; Pajares \& Graham, 1999; Schunk, 1991; Zimmerman, Bandura \& Martinez-Pons, 1992) ve öğrenme stratejilerini daha az kullandıkları (Paterson, 1996; Soung, 2001; Zimmerman \& Risemberg, 1997) ortaya çıkmıştır. Bu konuda yapılan araştırmalarda matematik başarısı ile öz-düzenleyici öğrenme arasında olumlu yönde ilişki olduğu (Arsal, 2009; Ataş, 2009; Cab1 \& Gülbahar, 2008; Cab1, 2009; Canca, 2005; Fuchs ve ark., 2003; Küçük-Özcan, 2000; Malpass, O'neil, Harold \& Hocevar, 1999; Özturan-Sağırlı ve Azapağası, 2009; Turan ve Demirel, 2010) ve öz düzenleme stratejilerinin matematik başarısını açıklamada anlamlı bir yordayıcı olduğu (Alc1, Erden ve Baykal, 2006; Altun, 2005; Öztürk, Bulut \& Koç, 2007; Üredi, 2005; Yumuşak, Sungur \& Çakıroğlu, 2007; Yüksel, 2013) tespit edilmiştir.

Öğrenme ve başarı üzerinde etkili olduğu düşünülen bir diğer değişken epistemolojik inançlardır (Deryakulu, 2004; Muis, Bendixen \& Haerle; 2006; Schommer \& Dunnell, 1997). Epistemoloji terimi; felsefenin bilgi sorununu temel alarak, bilgiyle ilgili problemleri araştıran, bilginin doğasını, yapısını, kaynağını, kökenini, değerini, ölçütlerini, geçerliliğini ve sınırlarını inceleyen felsefe alanı olarak tanımlanmaktadır (Deryakulu ve Kuzgun, 2006; Hançerlioğlu, 1996; Pears, 2004; Yazıc1, 1999). Epistemolojik inançlar bireylerin; bilginin ne olduğu, bilme ve öğrenmenin nasıl gerçekleştiği, kesinliğinin derecesi, sınırları, organizasyonu ve ölçütleri üzerindeki görüşleri ile ilgili öznel inançları olarak tanımlanmaktadır. Okullarda öğrencilerin yeni bilgilerle karşılaştıktan sonra kavrama, yorumlama ve değerlendirme aşamalarını gerçekleştirebilmek için bilişsel ve duyuşsal süreçlerini harekete geçirmeleri gerekmektedir. Bu noktada devreye giren epistemolojik inançlar öğrencilerin bilişsel ve duyuşsal süreçlerini harekete geçirmelerinde, karşılaştıkları yeni bilgiyi tanımlamalarında, yapılandırmalarında, değerlendirmelerinde ve öğrenmenin gerçekleşmesinde rol oynamaktadır. Araştırmalar epistemolojik inançların öğrenmeyle 
dolayısıyla akademik başarı ile ilişkili olduğunu göstermiştir (Deryakulu, 2004; KoçErdamar ve Bangir-Alpan, 2011; Özkan, 2008; Schommer \& Dunnell, 1997; Uysal, 2010; Windschitl \& Andre, 1998).

Akademik başarıyı etkileyen önemli diğer bir değişken akademik benlik kavramıdır. Akademik benlik kavramı, öğrencinin öğrenme geçmişine dayalı olarak herhangi bir öğrenme birimini öğrenip öğrenemeyeceğine ilişkin kendini algılayış tarzıdır (Senemoğlu, 2010). Akademik benlik kavramı ile matematik başarısı arasında pozitif ilişki olduğunu ortaya koyan araştırmalar mevcuttur (Arseven, 1986; Çankaya, 2004; Guay, Marsh \& Boivin, 2003; Gürel, 1986; House, 1993; Karasakaloğlu ve Saracaloğlu, 2009; Marsh \& Yeung, 1997; Pehlivan ve Köseoğlu, 2010; Piyanc1, 2007; Senemoğlu, 1989).

Yurt içinde ve yurt dışında yapılan araştırmalar incelendiğinde, genel olarak özdüzenleme ve bilişsel strateji kullanımı ve akademik benlik algısı ile akademik başarı arasındaki ilişkiyi incelemeye yönelik araştırmalar yapıldığı görülmektedir. Epistemolojik inançlar ile ilgili yapılan araştırmalar incelendiğinde, daha çok epistemolojik inançların öğrenme yaklaşımları ve fen başarısı (akademik başarı) ile arasındaki ilişki ve epistemolojik inançların cinsiyete, sınıf seviyesine, öğrenim görülen alana etkisi üzerinde yoğunlaşıldığı görülmektedir. Araştırma sonuçları, öz düzenleme stratejileri ve motivasyonel inançların matematik başarısının güçlü birer yordayıcıları olduklarını (Haşlaman ve Aşkar, 2007; Pintrich \& De Groot, 1990; Üredi ve Üredi, 2005), gelişmiş epistemolojik inançlar ile akademik başarı arasında anlamlı ve olumlu yönde ilişki olduğunu (Cano, 2005; Demirel, 2014; Demirli, Türel ve Özmen, 2010; Özkan, 2008; Sapancı, 2012) ve akademik benlik kavramının akademik başarının güçlü bir yordayıcısı olduğunu göstermektedir (Koç, 2011; Nazlıçiçek, 2007; Stringer \& Heath, 2008; Şimşek, 2012).

$\mathrm{Bu}$ araştırmada, dokuzuncu sınıf öğrencilerinin öz-düzenleyici öğrenme stratejileri, epistemolojik inançları ve akademik benlik kavramlarının matematik başarılarını yordama düzeyi nedir? sorusuna cevap aranmıştır. Araştırma sonucunda elde edilen bulguların, liselerde çalışan matematik öğretmenlerine ve lise yönetimlerine, öğrenme ortamlarının öğrencilerin öz-düzenleyici öğrenme stratejilerini geliştirmelerine olanak sağlayacak, epistemolojik inançların ve akademik benlik kavramının olumlu yönde değişimine imkân sağlayacak şekilde düzenlenmesi ve verilen matematik eğitiminin daha etkili hale getirilebilmesi konularında yol gösterici olabileceği düşünülmektedir. Türkiye'de matematik öğretim programı geliştirme çalışmalarında da araştırmanın bulgularından yararlanılabileceği düşünülmektedir.

\section{Yöntem}

\subsection{Araştırma Modeli}

$\mathrm{Bu}$ araştırmada, dokuzuncu sınıf öğrencilerinin öz-düzenleyici öğrenme stratejileri, epistemolojik inançları ve akademik benlik kavramları ile matematik başarıları 
arasındaki ilişkinin yönü ve derecesi belirlenmesi amaçlandığından ilişkisel tarama modeli kullanılmıştır. İlişkisel tarama modeli, iki ve daha çok sayıdaki değişken arasında birlikte değişim varlığ ve/veya derecesini belirlemeyi amaçlayan araştırma modelidir (Karasar, 2012, s.81).

\subsection{Evren ve Örneklem}

Araştırmanın çalışma evrenini 2013-2014 eğitim öğretim yılı İstanbul ili Avrupa yakasında bulunan tüm liselerde öğrenim gören dokuzuncu sınıf öğrencileri oluşturmaktadır. Araştırmanın dokuzuncu sınıf öğrencileri ile yapılmasının nedeni dokuzuncu sınıf matematik dersi öğretim programının sonraki yıllarda görülecek matematik konuları için temel oluşturması, ortaöğretim kurumlarında uygulanan matematik programı ve matematik dersinin haftalık ders saatinin tüm dokuzuncu sınıflarda eşit olmasıdır. Örneklem oluşturma sürecinde öncelikle, İstanbul İl Milli Eğitim Müdürlüğü'nün resmi sitesindeki ortaöğretim kurumları listesinden yararlanılarak Avrupa yakasındaki ortaöğretim kurumlarının sayısının 400 olduğu tespit edilmiştir. $\mathrm{Bu}$ ortaöğretim kurumları 1'den 400'e kadar numaralandırılmıştır. $\mathrm{Bu}$ numaraların olduğu kâğıtlar bir torbaya konulmuş ve rastgele okul ismi çekilmiştir. 10 asıl 20 yedek olmak üzere 30 okul seçilmiştir. Araştırmanın örneklemi, seçkisiz küme örnekleme yöntemiyle belirlenen on ortaöğretim kurumunda öğrenim gören toplam 630 öğrenciden oluşmuştur. Örnekleme giren ilçe, okul türü ve öğrenci sayıları Tablo 1'de verilmiştir.

Tablo 1. Örnekleme giren ilçe, okul türü ve öğrenci sayıları

\begin{tabular}{ccc}
\hline İlçe Adı & Lise Türü & Öğrenci Sayısı \\
\hline Bağcılar & Meslek Lisesi & 75 \\
\hline Güngören & Anadolu Lisesi & 70 \\
\hline Zeytinburnu & Anadolu Lisesi & 75 \\
\hline Küçükçekmece & Anadolu Lisesi & 70 \\
\hline Gaziosmanpaşa & Anadolu Lisesi & 60 \\
\hline Eyüp & Anadolu Lisesi & 60 \\
\hline Esenler & Çok Programlı Lise & 50 \\
\hline Beşiktaş & Anadolu Lisesi & 50 \\
\hline Şişli & Meslek Lisesi & 50 \\
\hline Esenyurt & Anadolu Lisesi & 70 \\
\hline Toplam & & $\mathbf{6 3 0}$
\end{tabular}

Tabloda belirtilen yedi farklı Anadolu Lisesi, iki farklı Meslek lisesi ve bir Çok Programlı lisede, veri toplama araçlarının uygulanması için izin alınan tarihler aralığında eğitim-öğretimi aksatmamaya özen gösterilerek ve katılımcıların gönüllülük esasını göz önünde bulundurularak uygulama yapılmıştır. Uygulama yapılan liselerde veri toplama araçlarını yönergeye uygun eksiksiz doldurulan öğrenci sayısı toplamı 630 dur. 


\subsection{Veri Toplama Araçları}

Araştırmada veri toplamak amacıyla aşağıda belirtilen ölçekler ve matematik başarı testi kullanılmıştır.

\subsection{1. Öğrenmeye İlişkin Motivasyonel Stratejiler Ölçeği}

Araştırmada öğrencilerin öz-düzenleyici öğrenme stratejileri, Pintrich ve De Groot (1990) tarafından geliştirilen 44 maddeden oluşan yedi dereceli Likert tipi "Öğrenmeye İlişkin Motivasyonel Stratejiler Ölçeği (Motivated Strategies for Learning Questionnaire)" nde yer alan 'Öz düzenleme' ve 'Bilişsel strateji kullanımı' alt boyutları aracılığıyla ölçülmüştür. Orijinal ölçekte, söz konusu ders için davranışlar tanımlayan 44 madde bulunmaktadır. Akademik performansa ilişkin öz-düzenleyici öğrenme stratejilerini kullanım düzeyini ve motivasyonel inançları ölçmek amacıyla yedinci sınıf öğrencilerine yönelik geliştirilen ölçeğin Türkiye koşullarına uyarlama çalışması Üredi (2005) tarafından gerçekleştirilmiştir. Ölçek, öz-düzenleyici öğrenme stratejileri ve motivasyonel inançlar olmak üzere iki boyuttan oluşmaktadır. Öz-düzenleyici öğrenme stratejileri boyutu bilişsel strateji kullanımı (13 madde) ve öz düzenleme ( 9 madde) olmak üzere iki alt ölçekten; motivasyonel inançlar boyutu ise özyeterlik ( 9 madde), içsel değer ( 9 madde) ve sinav kaygısı (4 madde) olmak üzere üç alt ölçekten oluşmaktadır. Orijinal ölçeğin iç tutarlık (Cronbach alfa) katsayıları sırasıyla; bilişsel strateji kullanımı boyutu için .83 ve öz düzenleme boyutu için .74'dür (Pintrich \& De Groot, 1990). Ölçeğin Türkçe formunda iç tutarlık (Cronbach alfa) katsayıları sırasıyla; bilişsel strateji kullanımı ölçeği için .82 ve öz düzenleme ölçeği için .84'dür (Üredi, 2005). Bu araştırma için Öğrenmeye İlişkin Motivasyonel Stratejiler Ölçeği'nin (ÖİMSÖ) geçerlik ve güvenirlik çalışması 2012-2013 eğitim öğretim yılında İzmir ili Urla ilçesinde bulunan farklı türde eğitim veren altı lisede 374 dokuzuncu sınıf öğrencisine uygulanarak yapılmıştır. Öğrenmeye İlişkin Motivasyonel Stratejiler Ölçeğinin öz düzenleme ve bilişsel strateji kullanımı alt ölçekleri için yapılan birinci düzey DFA sonucunda $\chi^{2}=576,71 ; \mathrm{sd}=208 ; \chi 2 / \mathrm{sd}=2.77 ; \mathrm{p}=0.00 ; \mathrm{AGFI}=.85$, GFI $=.88$, $\mathrm{NNFI}=.92, \mathrm{CFI}=.93, \quad \mathrm{~S}-\mathrm{RMR}=.060$ ve RMSEA=.062 olarak elde edilmiştir. Öz düzenleme ölçeğinde bulunan 7. ve 8. maddelerin (uygulanan ölçekte 25 ve 24.madde) $t$ değerleri manidar olmadığı için bu iki madde sırayla analizden çıkarıldıktan sonra öz düzenleme ve bilişsel strateji kullanımı alt ölçekleri için tekrarlanan DFA sonucunda $\chi^{2}=507,88 ; \mathrm{sd}=169 ; \chi^{2 / \mathrm{sd}}=3 ; \mathrm{p}=0.00 ; \mathrm{AGFI}=.85, \mathrm{GFI}=.88, \mathrm{NNFI}=.92 \mathrm{CFI}=.93, \mathrm{~S}-$ $\mathrm{RMR}=.069$ ve RMSEA=.062 olarak elde edilmiştir. Cronbach Alfa katsayıları öz düzenleme ölçeğinde .68 ve bilişsel strateji kullanımı ölçeğinde .84 olarak hesaplanmıştır.

\subsubsection{Matematik Odaklı Epistemolojik İnançlar Ölçeği}

Araştırmada öğrencilerin epistemolojik inançlarını belirlemek amacıyla İlhan ve Çetin (2013) tarafindan geliştirilen "Matematik Odaklı Epistemolojik İnançlar Ölçeği (MOEİ̈)" kullanılmıştır. Matematik Odaklı Epistemolojik İnançlar Ölçeği; Öğrenmenin 
Çabaya Bağlı Olduğuna İnanç (ÖÇBOİ), Öğrenmenin Yeteneğe Bağlı Olduğuna İnanç (ÖYBOİ) ve Tek Bir Doğrunun Var Olduğuna İnanç (TBDVOİ) olmak üzere üç alt boyuttan oluşmaktadır. ÖÇBOİ boyutu 10 madde, ÖYBOİ boyutu 10 madde ve TBDVOİ boyutun yedi madde olmak üzere toplamda 27 maddeden oluşan ölçek, Kesinlikle Katıliyorum (5), Katılıyorum (4), Kararsızım (3), Katılmıyorum (2) ve Kesinlikle Katılmıyorum (1) şeklinde beşli Likert tipi bir derecelendirme ölçeğidir. Ölçekte iki madde olumsuz olduğundan tersten puanlanmıştır. MOEİÖ’nün ÖÇBOİ alt ölçeğinden alınan yüksek puanlar matematik alanına yönelik gelişmiş/olgunlaşmış epistemolojik inançlara işaret ederken; ÖYBOİ ve TBDVOİ alt ölçeklerinden alınan yüksek puanlar matematik alanına yönelik gelişmemiş/olgunlaşmamış epistemolojik inançlara işaret etmektedir. MOEİÖ'nün güvenirliği, iç tutarlık ve test-tekrar test yöntemleriyle incelenmiştir. Hesaplanan iç tutarlık katsayıları ÖÇBOİ alt ölçeği için .84, ÖYBOİ alt ölçeği için .81 ve TBDVOİ alt ölçeği için .71 şeklindedir. Test-tekrar test güvenirlik katsayıları ise ÖÇBOİ alt ölçeği için .96, ÖYBOİ alt ölçeği için .95 ve TBDVOİ alt ölçeği için .95 olarak bulunmuştur (İlhan ve Çetin, 2013). Bu araştırma kapsamında Matematik Odaklı Epistemolojik İnançlar Ölçeğinin (MOEIÖ) geçerlik ve güvenirlik çalışması 2013-2014 eğitim öğretim yılında İstanbul ili Bağcılar ilçesinde bulunan farklı türde eğitim veren beş lisede 381 dokuzuncu sınıf öğrencisine uygulanarak yapılmıştır. Epistemolojik İnançlar Ölçeğinin alt ölçekleri için yapılan birinci düzey DFA sonucunda $\chi^{2}=735,19 ; \mathrm{sd}=321 ; \chi 2 / \mathrm{sd}=2.29 ; \mathrm{p}=0.00 ; \mathrm{AGFI}=.85$, $\mathrm{GFI}=.87, \mathrm{NNFI}=.92 \mathrm{CFI}=.92, \mathrm{~S}-\mathrm{RMR}=.071$ ve $\mathrm{RMSEA}=.058$ olarak elde edilmiştir. Epistemolojik İnançlar Ölçeğinin 27. Maddesinin t değeri manidar olmadığg için bu madde analizden çıkarıldıktan sonra Epistemolojik İnançlar Ölçeğinin alt ölçekleri için tekrarlanan DFA sonucunda $\chi^{2}=650,26 ; \mathrm{sd}=296 ; \chi 2 / \mathrm{sd}=2.19 ; \mathrm{p}=0.00$; $\mathrm{AGFI}=.86, \mathrm{GFI}=$ $.86, \mathrm{NNFI}=.92 \mathrm{CFI}=.93, \mathrm{~S}-\mathrm{RMR}=.068$ ve $\mathrm{RMSEA}=.056$ olarak elde edilmiştir. Cronbach Alfa katsayıları Öğrenmenin çabaya bağlı olduğuna inanç ölçeğinde .81, öğrenmenin yeteneğe bağlı olduğuna inanç ölçeğinde .82 ve tek bir doğrunun var olduğuna inanç ölçeğinde .75 olarak hesaplanmıştır.

\subsubsection{Akademik Benlik Kavramı Ölçeği}

Araştırmada öğrencilerin akademik benlik algılarının belirlenmesi amacıyla Brookover (1964) tarafından geliştirilen Senemoğlu (1989) tarafından Türkçe'ye uyarlanan "Akademik Benlik Kavramı Ölçeği (ABKÖ)" kullanılmıştır. ABKÖ, beş dereceli Likert tipinde 12 maddeden oluşan tek boyutlu bir ölçektir. Ölçekten alınabilecek toplam puan 12 ile 60 arasında değişmektedir. Ölçeğin uyarlanma çalışmaları sırasında üç farklı grupta elde edilen güvenilirlik katsayıları ortanca .84 olmak üzere .80 ile .89 arasında değişmektedir (Senemoğlu, 1989). Bu araştırma kapsamında Akademik Benlik Kavramı Ölçeği’nin (ABKÖ) güvenirlik çalışması 20132014 eğitim öğretim yılında İstanbul ili Bağcılar ilçesinde bulunan farklı türde eğitim veren beş lisede 380 dokuzuncu sınıf öğrencisine uygulanarak yapılmıştır. Ölçeğin güvenirliği ilişkin hesaplanan Cronbach Alfa katsayısı .81 bulunmuştur. 


\subsubsection{Matematik Başarı Testi}

Matematik başarı testi, 2013-2014 eğitim öğretim yılında güncellenen Matematik Dersi Öğretim Programı'nda yer alan dokuzuncu sınıf yıllık planının birinci döneminde bulunan kazanımları ölçmektedir. Bu amaçla alanyazın taraması yapılmış, daha önce kullanılan matematik başarı testleri (Başer, 1996; Somar, 2009) ve bu çalışmanın araştırmacıları tarafından hazırlanan güvenirliği hesaplanmış başarı testi incelenmiş ve hazırlanan belirtke tablosundaki kazanımlara uygun maddelerden madde ayırıcilık ve güçlük katsayıları göz önüne alınarak 30 soruluk deneme formu hazırlanmıştır. Matematik başarı testinin deneme formu Bağcılar ilçesinde bulunan bir Anadolu Lisesi ve bir İmam Hatip Lisesi olmak üzere iki lisede toplam 200 öğrenciye uygulanmıştır. Toplam 200 öğrenciye uygulanan deneme formunun cevap kâğıtları en yüksek puandan en düşük puana doğru sıraya konmuştur. \%27'lik üst ve alt gruplar oluşturulup her bir maddenin madde güçlük ve ayırııılık katsayıları hesaplanmıştır. Matematik başarı testi deneme formunun ortalama güçlüğü 0.48 ve deneme formunun güvenirlik katsayısı 0.82 olarak hesaplanmıştır. Matematik başarı testi deneme formunda bazı hedefler için birden fazla madde olduğundan bu maddeler içerisinde öncelikle ayırıcılık gücü yüksek olan ortalama güçlükteki maddeler seçilerek 18 maddelik nihai test oluşturulmuştur. Nihai testin ortalama güçlüğü 0.49 ve güvenirlik katsayısı 0.80 olarak hesaplanmıştır.

\subsection{Verilerin Analizi}

Araştırmaya katılan öğrencilerin ölçek puanları ve matematik başarı testi puanlarının betimsel istatistikleri yapıldıktan sonra bağımsız değişkenler (öz-düzenleyici öğrenme, epistemolojik inançlar ve akademik benlik kavramı) ile bağımlı değişken (matematik başarısı) arasında doğrusal ilişki olup olmadığını belirlemek amacıyla Pearson kolerasyon katsayısı hesaplanmıştır. Araştırmada öz-düzenleyici öğrenme stratejileri, epistemolojik inançlar ve akademik benlik kavramının matematik başarısını yordama gücünü belirlemek amacıyla ise 'Çoklu Regresyon Analizi' yapılmışıtır.

\section{Bulgular}

Araştırma kapsamında ele alınan bağımsız değişkenlere (öz-düzenleyici öğrenme stratejileri, epistemolojik inançlar ve akademik benlik kavramı) ve bağımlı değişkene (matematik başarısı) ilişkin betimsel istatistik sonuçları Tablo 2'de sunulmuştur.

Tablo 2 incelendiğinde, öz-düzenleyici öğrenme stratejileri ölçeğinin bilişsel strateji kullanımı ve öz düzenleme alt ölçeklerine ait aritmetik ortalamaların sırasıyla 63,43 ve 30,24 olduğu görülmektedir. Epistemolojik inançlar ölçeğinin, öğrenmenin çabaya bağl1 olduğuna olan inanç (ÖÇBOİ), öğrenmenin yeteneğe bağlı olduğuna olan inanç (ÖYBOİ) ve tek bir doğrunun var olduğuna inanç (TBDVOI) alt ölçeklerine ait aritmetik ortalamalarının 18,06 ile 37,29 arasında değerler aldığı görülmektedir. Akademik benlik kavramı ölçeğinin aritmetik ortalaması 27,54 olarak hesaplanmıştır. Matematik başarı testi puanlarının aritmetik ortalaması ise 6,88 olarak hesaplanmıştır. 
Tablo 2. Öz-düzenleyici öğrenme stratejileri, epistemolojik inançlar, akademik benlik kavramı ve matematik başarısı değişkenlerine ilişkin betimsel istatistikler $(n=630)$

\begin{tabular}{ccccc}
\hline Değişkenler & $\begin{array}{c}\text { Alınan } \\
\text { Minimum Puan }\end{array}$ & $\begin{array}{c}\text { Alınan } \\
\text { Maksimum } \\
\text { Puan }\end{array}$ & Ortalama & Std. Sapma \\
\hline $\begin{array}{c}\text { Bilişsel strateji } \\
\text { kullanımı }\end{array}$ & 18 & 90 & 63,43 & 12,51 \\
\hline Öz düzenleme & 10 & 48 & 30,24 & 6,78 \\
\hline ÖÇBOİ & 11 & 50 & 37,29 & 7,14 \\
\hline ÖYBOİ & 10 & 50 & 28,36 & 8,30 \\
\hline TBDVOİ & 6 & 30 & 18,06 & 5,39 \\
\hline $\begin{array}{c}\text { Akademik benlik } \\
\text { kavramı }\end{array}$ & 8 & 40 & 27,54 & 6,16 \\
\hline Matematik başarısı & 0 & 17 & 6,88 & 3,74 \\
\hline $\begin{array}{c}\text { ÖCBOİ: Öğrenmenin Cabaya Bağı Olduğuna İnanç } \\
\text { ÖYBOİ: Öğrenmenin Yeteneğe Bağı Olduğuna İnaņ̧ }\end{array}$ & & TBDVOİ: Tek Bir Doğrunun Var Olduğuna İnanç
\end{tabular}

Araştırmada yer alan bağımsız değişkenler ile matematik başarısı arasındaki ilişkinin incelenmesinde, normal dağılım gösteren öz-düzenleyici öğrenme stratejileri, epistemolojik inançlar, akademik benlik kavramı ve matematik başarısı değişkenleri için Pearson kolerasyon katsayısı hesaplanmıştır. Bağımsız değişkenler ile matematik dersi başarısı arasındaki ilişki düzeyleri Tablo 3'de sunulmuştur.

Tablo 3. Bağımsız değişken ile bağımlı değişkenler arasındaki kolerasyon analizi

\begin{tabular}{ccc}
\hline Değişkenler & $\mathbf{r}$ & $\mathbf{p}$ \\
\hline $\begin{array}{c}\text { Bilişsel strateji kullanımı \& } \\
\text { matematik başarısı }\end{array}$ & 0,095 & $0,017^{*}$ \\
\hline $\begin{array}{c}\text { Öz düzenleme \& matematik } \\
\text { başarısı }\end{array}$ & 0,071 & 0,073 \\
\hline ÖÇBOİ \& matematik başarısı & 0,041 & 0,303
\end{tabular}

ÖYBOİ \& matematik başarısı $\quad-0,052 \quad 0,191$

\begin{tabular}{ccc}
\hline $\begin{array}{c}\text { TBDVOİ \& matematik } \\
\text { başarısı }\end{array}$ & $-0,045$ & 0,255 \\
\hline $\begin{array}{c}\text { Akademik benlik kavramı \& } \\
\text { matematik başarısı }\end{array}$ & 0,313 & $0,000^{* *}$ \\
\hline
\end{tabular}

ÖÇBOI: Öğrenmenin Çabaya Bağlı Olduğuna İnanç

ÖYBOI: Öğrenmenin Yeteneğe Bağlı Olduğuna İnanç

TBDVOI: Tek Bir Doğrunun Var Olduğuna İnanç

Tablo 3 incelendiğinde bilişsel strateji kullanımı $(\mathrm{p}<.05)$ ve akademik benlik kavramı $(\mathrm{p}<.01)$ ile matematik başarısı arasındaki ilişkiler istatistiksel olarak anlamlı bulunmuştur. Bununla birlikte öz düzenleme ve epistemolojik inançlar (öğrenmenin çabaya bağlı olduğuna inanç, öğrenmenin yeteneğe bağlı olduğuna inanç ve tek bir 
doğrunun var olduğuna inanç) ile matematik başarısı arasındaki ilişkiler istatistiksel olarak anlamlı bulunmamıştır. İncelenen tabloda çoklu regresyon analizinde yordayıcı değişken olarak ele alınabilecek değişkenlerin bilişsel strateji kullanımı ve akademik benlik kavramı olduğu görülmektedir. Bilişsel strateji kullanımı ve akademik benlik kavramı değişkenlerinin matematik başarısını yordama düzeyi Tablo 4'te sunulmuştur.

Tablo 4. Bilişsel strateji kullanımı ve akademik benlik kavramının matematik başarısını yordama gücü

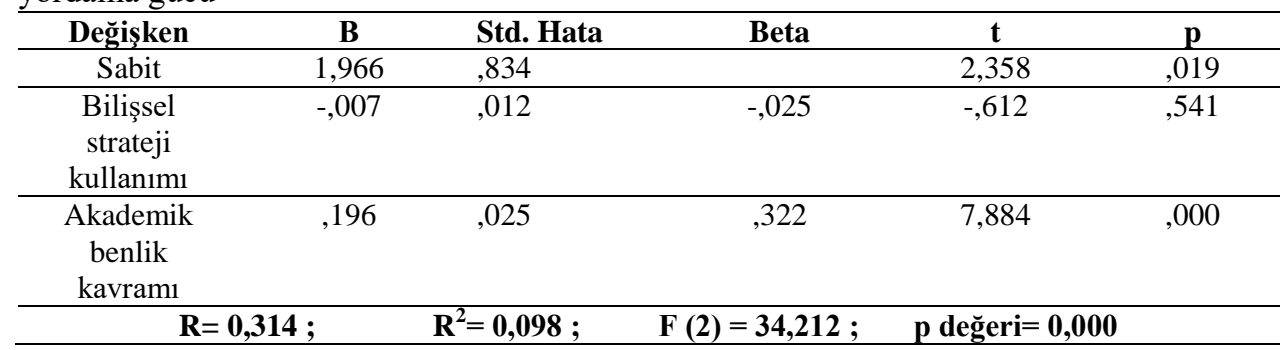

Tablo 4'te verilen $\mathrm{F}$ değeri ve $\mathrm{p}$ değeri incelendiğinde, $\mathrm{p}$ değeri 0,05 değerinden küçük olduğundan matematik başarısını bilişsel strateji kullanımı ve akademik benlik kavramı değişkenlerinden en az biri ile tahmin etmenin istatistiksel olarak mümkün olduğu görülmektedir (Sipahi, Yurtkoru ve Çinko 2010). Bağımsız değişkenlerden bilişsel strateji kullanımı değişkeninin p değeri 0,05 den büyük olduğundan bu değişken modele anlamlı bir katkı sağlamamaktadır. Akademik benlik kavramı değişkeninin standardize edilmiş katsayı sütununa bakıldığında 0,322 olduğu ve akademik benlik kavramı değişkeninin $(\mathrm{t}=7,884, \mathrm{p}<.01)$ matematik başarısı için anlamlı bir yordayıcı olduğu görülmektedir. $\mathrm{R}$ ve $\mathrm{R}^{2}$ değerleri incelendiğinde modelin yordama gücü anlaşılmaktadır. Yapılan regresyon analizi sonucunda akademik benlik kavramı değişkeninin matematik başarısı değişkenini yordama gücünün $\% 10$ olduğu görülmektedir.

\section{Tartışma, Sonuç ve Öneriler}

$\mathrm{Bu}$ araştırmada, dokuzuncu sınıf öğrencilerinin bilişsel strateji kullanımı ile matematik başarısı arasında anlamlı ilişki $(\mathrm{p}<.05)$ olduğu bulunmuştur. Pintrich ve De Groot (1990) ile Üredi ve Üredi (2005) de, bilişsel strateji kullanımı ve akademik başarı arasında anlamlı bir ilişki olduğunu ortaya koymuşlardır. Bilişsel strateji kullanımı artıkça öğrencinin matematik başarı düzeyi artmaktadır. Araştırmada, dokuzuncu sınıf öğrencilerinin öz-düzenlemeleri ile matematik başarısı arasında anlamlı ilişki bulunmamıştır. Oysa Pintrich ve De Groot (1990) çalışmalarında, öz- düzenleme ve akademik başarı arasında anlamlı bir ilişki olduğu bulgusunu elde etmişlerdir. Alanyazında öz düzenleme ile akademik başarı arasındaki ilişki kuramsal olarak vurgulanmasına karşın, bu araştırmada elde edilen bulgu ile örtüşmemektedir. Araştırmada, dokuzuncu sınıf öğrencilerinin matematik başarısının öz-düzenleyici 
öğrenme stratejileri (öz düzenleme ve bilişsel strateji kullanımı) değişkeni tarafından anlamlı düzeyde yordanmadığı bulunmuştur. Özüdoğru (2013) da, ortaöğretim öğrencileri üzerinde yaptığı araştırmada öz düzenleme becerilerinin matematik başarılarını yordamadığını bulmuştur. Araştırmanın bulgusu bu bulgu ile örtüşmektedir. Ancak, bu bulgu, Pintrich ve De Groot (1990), Üredi ve Üredi (2005) ve Haşlaman ve Aşkar (2007) yaptıkları araştırmaların bulguları ile örtüşmemektedir. Örneğin, Haşlaman ve Aşkar (2007), üniversite öğrencileri üzerinde yaptığı araştırmada öz-düzenleyici öğrenme stratejilerinin başarının \%71' ini açıkladığını ortaya koymuşlardır. Araştırma sonuçlarının farklı olmasının nedeni, örneklemlerin özellikleri, farklı ölçme araçlarının kullanılması, söz konusu ölçümlerin psikometrik niteliklerinin gruplar arası farklılaşması, öğrenim görülen şartlar ve öğrencilerin başarı puanlarının belirlenmesinde kullanılan yöntemin farklı olması olabilir. Olaussen ve Braten'e (1999) göre özdüzenleyici öğrenme stratejilerinin kullanımı üzerine farklı ülkeler ve farklı şartlarda daha fazla çalışma yapılmalıdır. Bu tür sonuçların ortaya çıkmasında öğrencilerin öğrenim gördüğü şartlar ve programların özellikleri etkili olabilir.

Araştırmada dokuzuncu sınıf öğrencilerinin epistemolojik inançları (öğrenmenin çabaya bağlı olduğuna inanç, öğrenmenin yeteneğe bağlı olduğuna inanç ve tek bir doğrunun var olduğuna olan inanç) ile matematik başarıları arasında anlamlı bir ilişki bulunmamıştır. Alanyazında bu bulguyu destekleyen araştırmaların (Belet ve Güven, 2011) yanında epistemolojik inançlar ile matematik başarısı arasında anlamlı ilişsi bulan araştırmalar (Cano, 2005; Uysal, 2010) da bulunmaktadır. Araştırmada dokuzuncu sınıf öğrencilerinin matematik başarısının epistemolojik inançlar (öğrenmenin çabaya bağlı olduğuna inanç, öğrenmenin yeteneğe bağlı olduğuna inanç ve tek bir doğrunun var olduğuna olan inanç) değişkeni tarafından anlamlı düzeyde yordanmadığı görülmüştür. Bu bulgu, Cano ve Rodriguez (2006) ve Phan'ın (2008) yaptığı araştırmaların bulguları ile örtüşmemektedir. Örneğin Phan (2008), üniversite öğrencilerinin epistemolojik inançlarının akademik başarılarını doğrudan yordadığını bulmuştur. Bu durumun olası nedeni örneklemlerin özellikleri, farklı ölçme araçlarının kullanılması, söz konusu ölçümlerin psikometrik niteliklerinin gruplar arası farklılaşması ve öğrencilerin başarı puanlarının belirlenmesinde kullanılan yöntemin farklı olması olabilir. Bu araştırmanın yapıldığı ilçelerin çoğunluğunda genel olarak ailelerin eğitim düzeyleri ve sosyoekonomik durumlarının düşük düzeyde olması da, öğrencilerin epistemolojik inançlarını olumsuz yönde etkilemiş olabilir. Epistemolojik inançların geliştirilmesinde özdüzenleyici öğrenme büyük rol oynamaktadır (Muis, 2007). Epistemolojik inançlar, öğrencilerin öğrenme sürecinde kullandıkları bilişsel ve bilişüstü stratejilerini doğrudan, akademik başarılarını ise dolaylı olarak etkiler ve onlardan etkilenir (Cano, 2005; Deryakulu, 2004). Öğrencilerin epistemolojik inançları öz-düzenleyici öğrenme stratejilerine etki ettiğinden bu araştırmada öz-düzenleyici öğrenme stratejileri ve epistemolojik inançlar değişkenlerin her ikisinin de akademik başarıyı anlamlı düzeyde yordamadığı sonucu ortaya çıkmış olabilir.

Araştırmada dokuzuncu sınıf öğrencilerinin akademik benlik kavramı ile matematik başarısı arasında anlamlı ilişki $(\mathrm{p}<.01)$ olduğu ortaya çıkmıştır. Bu bulgu, Arseven (1986), Çankaya (2004), Dickhäuser (2005) ve Nazlıçiçek'in (2007) yaptığ 
araştırmaların bulguları ile örtüşmektedir. $\mathrm{Bu}$ araştırmada, dokuzuncu sınıf öğrencilerinin matematik dersi başarısının akademik benlik kavramı değişkeni tarafından anlamlı düzeyde yordandığı (\%10) bulunmuştur. Bu bulgu, Senemoğlu (1989), Stringer ve Heath (2008) ve Şimşek (2012) yaptıkları araştırmaların bulguları ile örtüşmektedir. Stringer ve Heath (2008), ortaöğretim öğrencileri üzerinde yaptığı araştırmada benlik algısının akademik başarıdaki varyansın \%25'ini açıkladığını ortaya koymuştur. Şimşek (2012) ise, üniversite öğrencileri üzerinde yaptığı araştırma sonucunda akademik benlik algısının akademik başarının yordayıcısı olduğunu ve akademik benlik algısının akademik başarıdaki varyansın \%40'ını açıkladığını tespit etmiştir.

Araştırma sonucunda, dokuzuncu sınıf öğrencilerinin bilişsel strateji kullanımı ve akademik benlik kavramı ile matematik başarısı arasında anlamlı bir ilişki olduğu ve matematik dersi başarısının akademik benlik kavramı değişkeni tarafından anlamlı düzeyde yordandığı (\%10) bulunmuştur. Araştırma sonuçları dikkate alınarak ortaöğretim matematik dersi programı, öğrencilerin bilişsel strateji kullanımı ve akademik benlik kavramının gelişimine yardımcı olabilecek şekilde tasarlanabilir ve geliştirilebilir. Öğrencilerin bilişsel strateji kullanımı ve akademik benlik kavramını geliştirebilecekleri seminer, konferans gibi etkinlikler düzenlenerek öğrencilerin farkındalık düzeyleri yükseltilebilir. Öğretim programının uygulayıcıları olan öğretmenler, öğrencilerin bilişsel strateji kullanımını nasıl geliştirebileceği ve akademik benlik kavramı düzeylerini nasıl yükseltebileceği konusunda bilgilendirilmelidir. $\mathrm{Bu}$ amaçla öğretmenlere yönelik hizmet öncesi öğretmen eğitimi programında bu becerilerin kazandırılmasına yönelik etkinlikler yapılabilir, hizmet içi eğitim kursları ve seminerler düzenlenebilir. Aynı araştırma, çalışma evreni genişletilerek bölgesel ya da ulusal düzeyde yapılabilir. Ayrıca, bu araştırmada küme örnekleme yöntemi kullanılmıştır. Araştırma aynı değişkenler ile farklı örnekleme yöntemleri kullanılarak tekrar edilebilir. $\mathrm{Bu}$ araştırmanın örneklemini dokuzuncu sınıf öğrencileri oluşturmaktadır. Matematik dersi başarısına yönelik daha kapsamlı bir araştırma yapılabilmesi amacıyla diğer sınıf düzeylerinde de öğrencilerin matematik dersi başarısı incelenebilir. Öz-düzenleyici öğrenme stratejileri, epistemolojik inançlar ve akademik benlik kavramını belirlemeye yönelik farklı veri toplama araçları kullanılarak araştırma yenilenebilir. Ülkemizde yapılan araştırmaların çoğunluğu betimsel araştırmadır. Öz-düzenleyici öğrenme stratejileri, epistemolojik inançlar ve akademik benlik kavramı değişkenlerinin matematik dersi başarısı üzerindeki etkisini inceleyen deneysel araştırmalar yapılabilir. Araştırmada ele alınan öz-düzenleyici öğrenme stratejileri, epistemolojik inançlar ve akademik benlik kavramı değişkenlerinden sadece akademik benlik kavramı değişkeninin matematik dersi başarısındaki varyansın \%10'unu açıklamış olması, matematik dersi başarısındaki \%90'lık bölümün açıklanması gerektiğini ortaya koymaktadır. Matematik dersi başarısı ile ilgili diğer değişkenlerin bulunabilmesi için farklı değişkenleri içeren yeni araştırmalar yapılabilir. 


\section{The Relationship between Mathematics Achievement, Self-Regulated Learning Strategies, Epistemological Beliefs and Academic Self- Concept}

\section{Extended Abstract}

Mathematics is one of significant tools that we use to solve the issues and encounter in science and daily life (Baykul, 2000). The need for people who can understand mathematics and use mathematical skills and knowledge in daily life are increasing. Therefore, mathematics achievements take part in every stage of education. Mathematics achievement has an important position in the selection and placement of students at national and international level and acceptance of students for many educational institutions. The results of international (PISA and TIMSS) and national exams to measure the mathematics achievement is guide for educators. Therefore, it is important to investigate the factors that affect mathematics achievement.

One of the considered variables that affect academic performance and achievement is selfregulated learning (Boekaerts, 1996). Self-regulated learning is that an individual makes judgement by observation of his behavior and by comparing with his criteria, and individual behavior, if necessary, fit his criteria (Bandura, 1997). Another considered variable impacted on learning and achievement is epistomological beliefs (Deryakulu, 2004; Muis, Bendixen \& Haerle, 2006; Schommer \& Dunnell, 1997). Epistomological beliefs are defined as subjective beliefs of individuals about what information is, how it is carried out to learn and know, the level of its certainty, its boundaries, its organization and its views on its criteria. The other important variable that affects learning processes and achievement is academic self-concept. Academic self-concept is a self-perception of whether a student can learn any unit of learning based on his learning history (Senemoğlu, 2010). It is very important to determine the factors affecting mathematics achievement in terms of development of mathematics learning and teaching process. In this research, the correlation between mathematics achievement, and self-regulating learning strategy, epistemological beliefs and academic self-concept has been investigated and those variables have come forward in many researches. In this study, it has been try to answer this question: What is the predicted level of self-regulated learning strategies, epistemological beliefs and academic self-concept of ninth grade students?

In the study, a correlational survey model was used. Study population is composed of the ninth grade students in all high schools in the province of İstanbul in 2013-2014 academic year. The sample of study was consisted of a total of 630 students studying at ten secondary education institutions determined by random cluster sampling method. Self-regulated learning strategies of students in the study were measured by sub-dimensions of the use of 'Self-regulation' and 'Cognitive Strategy' found in a 44-item Likert type "Motivated Strategies for Learning Questionnaire" that develops by Pintrich \& De Groot (1990). The adaptation study of the scale to the conditions of Turkey was carried out by Üredi (2005). The "Mathematically Focused Epistemological Beliefs Scale (MFEBS)" developed by İlhan 
and Çetin (2013) was used to determine the epistemological beliefs of the students in the study. "Academics Self-Concept Scale (ASCS)" developed by Brookover (1964) and adapted to Turkish language by Senemoğlu (1989) was used to determine the student academic self-perceptions. The mathematics achievement of students was also measured through which they get score from mathematics achievement test. For the purpose of the study, the correlation between the predictor variables and the predicted variables was examined using correlation and multiple regression analysis techniques.

The results showed that there was no statistically meaningful correlation between selfregulation and epistemological beliefs and mathematics achievement while there was a statistically meaningful correlation between cognitive strategy use and academic selfconcept and mathematics achievement. Also, it was shown that the mathematics achievement was significantly predicted $(10 \%)$ by the variable of academics self-concept. The variables, self-regulated learning strategy and epistemological belief, did not predict mathematics achievement at a significant level. The results revealed that there was a meaningful correlation $(\mathrm{p}<.05)$ between mathematics achievement and cognitive strategy use. This result has been consistent with study findings of Pintrich and De Groot (1990), Üredi and Üredi (2005). There was no meaningful correlation between the epistemological beliefs (the beliefs that the learning depends on the effort, that the learning depends on the ability and that there is a single truth) and mathematics achievement of ninth grade students in the study. In addition to studies supporting this finding in literature (Belet \& Güven, 2011), there are also studies that find a meaningful correlation between epistemological beliefs and mathematics achievement (Cano, 2005; Uysal, 2010). In the study, it was shown that the mathematics achievement of the ninth grade students was not significantly predicted by variables of epistemological beliefs (the beliefs that the learning depends on the effort, that the learning depends on the ability and that there is a single truth). This finding has not been consistent with findings of Cano and Rodriguez (2006), Phan (2008). In the study, it was found that the ninth grade students had a meaningful correlation ( $\mathrm{p}<$ $.01)$ between academic self-concept and mathematics achievement. This finding has been consistent with study findings of Arseven (1986), Çankaya (2004), Dickhäuser (2005) and Nazlıçiçek (2007). This study showed that the mathematics achievement of the ninth grade students was significantly predicted $(10 \%)$ by the variable of academics self-concept. This finding has been consistent with study findings of Senemoğlu (1989), Stringer and Heath (2008), Şimşek (2012). Taking into consideration the results of the investigation, the secondary school mathematics curriculum can be designed and developed so that it can help the students to develop the academic self-concept and the use of cognitive strategy. The level of awareness of the students can be promoted by organizing activities such as seminars and conferences in which students can use the cognitive strategy and develop the academic self-concept. Teachers, practitioners of the curriculum, should be informed about how pupils can improve the use of cognitive strategy and how they can improve the level of academic self-concept. For this purpose, it can be organized the activities for teachers to 
gain these skills in pre-service teacher training program as well as in-service training courses and seminars can be organized.

\section{Kaynaklar/References}

Ader, N. E. (2004). A self- regulation model to explain quantitative achivement in a high stakes testing situation (Master's thesis). Boğaziçi Üniversitesi, İstanbul.

Alc1, B., Erden, M. ve Baykal, A. (2006). Üniversite öğrencilerinin matematik başarıları ile algıladıkları problem çözme becerileri, özyeterlik algıları, üstbiliş özdüzenleme stratejileri ve ÖSS sayısal puanları arasındaki açıklayıcı ve yordayıcı ilişkiler örüntüsü. Boğaziçi Eğitim Dergisi, 25(2), 53-68.

Altun, S. (2005). Öğrencilerin öz düzenlemeye dayalı ögrenme stratejilerinin ve öz yeterlik algılarının ögrenme stilleri ve cinsiyete göre matematik başarısını yordama gücü (Doktora tezi). Yıldız Teknik Üniversitesi, İstanbul.

Anderson, J. O., Rogers, W. T., Klinger, D. A., Ungerleider, C., Glickman, V., \& Anderson, B. (2006). Student and school correlates of mathematics achievement: Models of school performance based on pan canadian student assessment. Canadian Journal of Education, 29(3), 706-730.

Arsal, Z. (2009). Öz-düzenleme öğretiminin ilköğretim öğrencilerinin matematik başarısına ve tutumuna etkisi. Ĕgitim ve Bilim, 24(152), 3-14.

Arseven, D. (1986). Çocukta benlik gelişimine ailenin etkisi ve çocuğun okuldaki başarısı. Ĕ̈itim ve Bilim, 11, 17.

Ataş, İ. (2009). Öz düzenleyici ögrrenme stratejileri kullanımının ilköğretim okulu dördüncü sinıf ögrencilerinin matematik dersindeki öz yeterlik algısına ve başarısına etkisi (Yüksek lisans tezi). Gazi Üniversitesi, Ankara.

Bandura, A. (1997). Self-efficacy: The exercise of control. America, USA: W.H. Freeman and Company.

Başer, N. (1996). Ders geçme ve kredi sisteminde lise öğrencileri için bir matematik başarı testi tasarımı ve uygulanabilirliğinin araştırılması (Doktora tezi). Dokuz Eylül Üniversitesi, İzmir.

Baykul, Y. (2000). Illköğretimde matematik ögretimi (1.baskı). Ankara: Pegem Yayıncılık.

Belet, S. ve Güven, M. (2011). Sınıf öğretmeni adaylarının epistemolojik inançlarının ve bilişüstü stratejilerinin incelenmesi. Kuram ve Uygulamada Ĕgitim Bilimleri Dergisi, 11(1), 51-57.

Boekaerts, M. (1996). Self-regulated learning at the junction of cognition and motivation. European Pyschologist, 1(2), 100-112.

Cab1, E., \& Gülbahar, Y. (2008, May1s). The effect of subject field and gender of preservice teachers on their preferred self-regulated learning strategies. Paper presented at VIII. International Educational Technology Conference, Eskişehir Anadolu Üniversitesi, Eşkiş̧ehir.

Cabı, E. (2009). Öz düzenlemeye dayalı karma ögrrenimin öğrenci başarısı ve motivasyonuna etkisi (Doktora tezi). Gazi Üniversitesi, Ankara. 
Canca, D. (2005). Cinsiyete göre üniversite ögrencilerinin kullandıkları bilişsel ve bilişüstü özdüzenleme stratejileri ile akademik başarlları arasındaki ilişki (Yüksek lisans tezi). Y1ldız Teknik Üniversitesi, İstanbul.

Cano, F. (2005). Epistemological beliefs and approaches to learning: Their change through secondary school and their influence on academic performance. British Journal of Educational Psychology, 75, 203-221.

Cano, F., \& Rodriguez, L. (2006). The epistemological beliefs, learning approaches and study orchestrations of university students. Studies in Higher Education, 31(5), 617636.

Çankaya, H. (2004). Lise öğrencilerinin akademik benlik kavramı ile matematik dersine yönelik tutumlarının başarılarına etkisi (Yüksek lisans tezi). Selçuk Üniversitesi, Konya.

Demirel, A. (2014). Fen bilgisi ögretmen adaylarının epistemolojik inançlarının cinsiyete, akademik başarıya ve sinıf düzeyine göre incelenmesi (Yüksek lisans tezi). Muğla Sitkı Koçman Üniversitesi, Muğla.

Demirli, C., Türel, Y. K. ve Özmen, B. (2010, Nisan). Bilişim teknolojileri ögretmen adaylarının epistemolojik inançlarının incelenmesi. Uluslararası Eğitim Teknolojileri Sempozyumu'nda sunulan bildiri, Boğaziçi Üniversitesi, İstanbul.

Deryakulu, D. (2004). Üniversite öğrencilerinin öğrenme ve ders çalışma stratejileri ile epistemolojik inançları arasındaki ilişki. Kuram ve Uygulamada Eğitim Yönetimi, 38, 230-249.

Deryakulu, D. ve Kuzgun, Y. (Ed.). (2006). Eğitimde bireysel farklıllklar. Ankara: Nobel Yayınevi.

Dickhäuser, O. (2005). A fresh look: Testing the internal/external frame of reference model with frame-specific academic self-concepts. Educational Research, 47(3), 279-290.

Emiroğlu, Ö. (2012). Öğrenciler matematik dersinden neden başarısız oluyor. http://www.aktuelegitim.com/ogrenciler-matematik-dersinden-neden-basarisizoluyor.html. adresinden 20.01.2014 tarihinde erişilmiştir.

Ernest. P. (1991). The philosopy of mathematics education. London: The Farmer Press.

Franke, L., \& Kazemi, E. (2001). Learning to teach mathematics: Focus on student thinking. Theory into Practice, Spring, 40(2), 102-109.

Fuchs, L. S., Funchs, D., Prentice, K., Burch, M., Hamlett, C. L., Owen, R., \& Schroeter (2003). Enhancing third grade student's mathematical problem solving with self regulated learning strategies. Journal of Educational Psychology, 95(2), 306-315.

Gray, E., \& Tall, D. (1992). Success and failure in mathematics: The flexible meaning of symbols as process and concept. Mathematics Teaching, 142, 6-10.

Guay, F., Marsh, W. H., \& Boivin. M. (2003). Academic self-concept and academic achievement: Developmental perspectives on their causal ordering. Journal of Educational Psychology, 95(1),124-136.

Gürel, H. (1986). Yabancı dil olarak Ingilizce öğrenme başarısı ile ögrencilerin akademik benlik tasarımları ve tutumları arasındaki ilişki (Doktora tezi). Hacettepe Üniversitesi, Ankara. 
Hançerlioğlu, O. (1996). Felsefe sözlüğü (10. bask1). İstanbul: Remzi Kitabevi.

Haşlaman, T. ve Aşkar, P. (2007). Programlama dersi ile ilgili öz-düzenleyici öğrenme stratejileri ve başarı arasındaki ilişkinin incelenmesi. Hacettepe Üniversitesi Eğitim Fakültesi Dergisi, 32,110-122.

House, D. J. (1993). Achievement-related expectancies, academic self-concept and mathematics performance of academically underprepared adolecent student. Journal of Genetic Psychology, 154(1), 61-71.

İlhan, M. ve Çetin, B. (2013). Matematik odaklı epistemolojik inançlar ölçeği (MOEİÖ): Geçerlik ve güvenirlik çalışması. Kuramsal Eğitimbilim Dergisi, 6(3), 359-388.

Karasakaloğlu, N. ve Saracaloğlu, A. (2009). Sınıf öğretmeni adaylarının Türkçe derslerine yönelik tutumları, akademik benlik tasarımları ile başarıları arasındaki ilişki. Yüzüncü Yll Üniversitesi Eğitim Fakültesi Dergisi, 6(1), 343-362.

Karasar, N. (2012). Bilimsel araştırma yöntemi. Ankara: Nobel Yayın Dağıtım.

Kocabaş, K. (2016). PISA 2015 sonuçlarl ve Türkiye. http://www.demecgazetesi.com/pisa-2015-sonuclari-ve-turkiye-makale,2510.html. adresinden 12.07.2016 tarihinde erişilmiştir.

Koç-Erdamar, G. ve Bangir-Alpan, G. (2011). Öğretmen adaylarının epistemolojik inançlar1. Journal of New Word Sciences Academy, 6(4), 2689-2698.

Koç, Ö. (2011). İlköğretim ögrrencilerinin Türkçe dersindeki akademik benlik kavramlarının başarılarına etkisinin incelenmesi (Yüksek lisans tezi). Dokuz Eylül Üniversitesi, İzmir.

Küçük-Özcan, Z. Ç. (2000). Teaching metacognitive strategies to 6th. grade students (Master's thesis). Boğaziçi Üniversitesi, İstanbul.

Malpass, J. R., O'neil, J., Harold, F., \& Hocevar, D. (1999). Self-regulation, goal orientation, self-efficacy, worry and high stakes math achievement for mathematically gifted high school students. Roeper Review, 21(4), 281-290.

Marsh, H. W., \& Yeung, A. S. (1997). Causal effects of academic self-concept on academic achievement: Structural equation models of longitudinal data. Journal of Educational Psychology, 89(1), 41-54.

Mcleod, D. B. (1992). Research on affect in mathematics education: A reconceptualization. In D. A. Grouws (Ed.), Handbook of research on mathematics teaching and learning (p. 575-596). New York: Macmillan.

Milli Eğitim Bakanlığı [MEB]. (2013). PISA 2012 ulusal ön değerlendirme raporu. Ankara: MEB.

Muis, K. R., Bendixen, L. D., \& Haerle, F. C. (2006). Domain-generality and domainspecificity in personal epistemology research: Philosophical and empirical reflections in the development of a theoretical framework. Educational Psychology Review, 18(1), 3-54.

Muis, K. (2007). The role of epistemic beliefs in self-regulated learning. Educational Psychologist, 42(3), 173-190.

Nasser, F., \& Birenbaum, M. (2005). Modeling mathematics achievement of jewish and arab eight graders in 1srael: The effects of learner-related variables. Educational Research and Evaluation, 11(3), 277-302.

Nazlıçiçek, N. (2007). Onuncu sınıf ögrencilerinin matematik başarılarını açıklayıcı bir model çalışması (Doktora tezi). Yıldız Teknik Üniversitesi, İstanbul. 
Olaussen, B. S., \& Braten, I. (1999). Students' use of strategies for self-regulated learning: Crosscultural perspectives. Scandinavian Journal of Educational Research, 43, 409432.

Öğrenci Seçme ve Yerleştirme Merkezi [ÖSYM]. (2012). 2012-YGS sonuçlarına ilişskin sayısal bilgiler. http://www.osym.gov.tr/belge/1-13604/2012-ygs-sonuclarina-iliskinsayisal-bilgiler.html adresinden 12.04.2014 tarihinde erişilmiştir.

Öğrenci Seçme ve Yerleştirme Merkezi [ÖSYM]. (2015). 2015-YGS sonuçlarına ilişskin saylsal bilgiler. http://www.osym.gov.tr/belge/1-23400/2015-ygs-sonuclarina-iliskinsayisal-bilgiler.html adresinden 25.03.2016 tarihinde erişilmiştir.

Özkan, Ş. (2008). İlköğretim öğrencilerinin fen başarıları ile ilgili bir modelleme çalışması: Epistomolojik inançlar, ögrenme yaklaşımları ve öz-düzenleme becerileri arasındaki ilişkiler (Doktora tezi). Orta Doğu Teknik Üniversitesi, Ankara.

Özturan-Sağırlı, M. ve Azapağası, E. (2009). Üniversite öğrencilerinin öğrenmede öz düzenlemeyi öğrenme becerilerinin incelenmesi. Ankara Üniversitesi Eğitim Bilimleri Fakültesi Dergisi, 42(2),129-161.

Öztürk, B., Bulut, S., \& Koç, Y. (2007). Motivation and self-regulation in mathematic. Academic Exchange Quarterly, 11(1), 149-154.

Özüdoğru, M. (2013). Dokuzuncu sınıf ögrrencilerinin matematik başarılarının yordanması (Yüksek lisans tezi). Ege Üniversitesi, İzmir.

Pajares, F., \& Graham, L. (1999). Self-efficacy, motivation constructs, and mathematics performance of entering middle school students. Contemporary Educational Psychology, 24, 124-139.

Paterson, C. (1996). Self-regulated learning and academic achivement of senior biology students. Australian Science Teacher Journal, 42(2), 48-53.

Pears, D. (2004). Bilgi nedir? (1. bask1). (A. Güçlü, Çev.). Ankara: Bilim ve Sanat Yayınları.

Pehlivan, H. ve Köseoğlu, P. (2010). Ankara Fen Lisesi Öğrencilerinin Biyoloji Dersine Yönelik Tutumları ile Akademik Benlik Tasarımları. Hacettepe Üniversitesi Eğitim Fakültesi Dergisi, 38, 225-235.

Phan, P. P. (2008). Exploring epistemolojical beliefs and learning apporaches in context: A sociocultural perspective. Electronic Journal of Research in Educational Psychology, 16(6), 793-822.

Pintrich, P. R., \& De Groot, E. V. (1990). Motivational and self-regulated learning components of classroom academic performance. Journal of Educational Psychology, $82,33-40$.

Piyancı, B. (2007). İlköğretim altıncı sınıf ögrrencilerinin bilgisayar dersindeki akademik benlik kavramları ile başarıları arasındaki ilişki (Yüksek lisans tezi). Dokuz Eylül Üniversitesi, İzmir.

Richardson, F. C., \& Suinn, R. M. (1972). The mathematics anxiety scale: Psychometric data. Journal of Counseling Psychology, 19(6), 551-554. 
Sapancı, A. (2012). Öğretmen adaylarının epistemolojik inançları ile bilişüstü düzeylerinin akademik başarıyla ilişkisi. Celal Bayar Üniversitesi, Sosyal Bilimler Dergisi, 10(1), 311-331.

Schommer, M., \& Dunnell, P. (1997). Epistemological beliefs of gifted high school students. Roeper Review, 19(3), 153-156.

Schunk, D. H. (1991). Self-efficacy and achievement behaivors. Educational Psychology Review, 1, 173-208.

Senemoğlu, N. (1989). Öğrenci giriş nitelikleri ve ögretme-ögrenme süreci özelliklerinin Matematik derslerindeki öğrenme düzeyini yordama gücü. Ankara: Hacettepe Üniversitesi.

Senemoğlu, N. (2010). Gelişim öğrenme ve öğretim. Ankara: Pegem A.

Sipahi, B., Yurtkoru, S. ve Çinko, M. (2010). Sosyal bilimlerde SPSS'le veri analizi. İstanbul: Beta Basım Yayım Dağıtım.

Somar, A. (2009). Ortä̈ğretimde matematik öğretmenlerinin liderlik stillerinin ögrencilerin matematik dersindeki başarı ve tutumu üzerine etkileri (Yüksek lisans tezi). Yeditepe Üniversitesi, İstanbul.

Soung, Y. K. (2001). Investing the relationship between motivational factor and self regulatory strategies in the knowledge construct process. Retrieved May 18, 2013 from http://www.icce.2001.org/cd/pdf/poster3/KR019.pdf.

Stafslien, C. (2001). Gender differences in achievement in mathematics. Retrieved March 15, 2012 from http://www.math.wisc.edu/ weinberg/MathEd/Gender_Term_Paper.doc.

Stringer, R., \& Heath, N. (2008). Academic self-perception and its relationship to academic performance. Canadian Journal of Education, 31(2), 327-345.

Suinn, R. M., \& Edwards, R. (1982). The measurement of mathematics anxiety. The mathematics anxiety rating scale for adolescents-MARS-A. Journal of Clinical Psychology, 38(3), 576-580.

Şimşek, A. S. (2012). Bilişsel ve duyuşsal özelliklerin yükseköğretimdeki akademik başarıyı yordama gücü (Yüksek lisans tezi). Ankara Üniversitesi, Ankara.

Turan, S. ve Demirel, Ö. (2010). Öz-düzenleyici öğrenme becerilerinin akademik başarı ile ilişkisi: Hacettepe üniversitesi tıp fakültesi örneği. Hacettepe Üniversitesi Eğitim Fakültesi Dergisi, 38, 279-291.

Uysal, E. (2010). Bir modelleme çalışması: Illköğretim öğrencilerinin epistemolojik inançları, ögrenme ortamları ile ilgili algıları, ögrenme yaklaşımları ve fen başarıları arasindaki ilişkiler (Doktora tezi). Ortadoğu Teknik Üniversitesi, Ankara.

Üredi, I. (2005). Algllanan anne baba tutumlarının ilköğretim 8. sinıf ögrencilerinin öz düzenleyici ögrenme stratejileri ve motivasyonel inançlarl üzerindeki etkisi (Doktora tezi). Yıldız Teknik Üniversitesi, İstanbul.

Üredi, I. ve Üredi, L. (2005). İlköğretim 8. sınıf öğrencilerinin öz-düzenleme stratejileri ve motivasyonel inançlarının matematik başarısını yordama gücü. Mersin Üniversitesi Eğitim Fakültesi Dergisi, 1(2), 250-260.

Windschitl, M., \& Andre, T. (1998). Using computer simulations to enhance conceptual change: The roles of constructivist instruction and students epistemological beliefs. Journal of Research in Science Teaching, 35(2), 145-160.

Yazıc1, S. (1999). Felsefeye giriş. İstanbul: Alfa Yayınları. 
Yenilmez, K. ve Duman, A. (2008). İlköğretimde matematik başarısını etkileyen faktörlere ilişkin öğrenci görüşleri. Sosyal Bilimler Dergisi, 19, 251-268.

Yumuşak, N., Sungur, S., \& Çakıroğlu, J. (2007). Turkish high school students biology achievement in relation to academic self-regulation. Educational Research and Evaluation, 13(1), 53-69.

Yüksel, İ. (2013). Öğretim stil tercihlerinin öz-düzenleme beceri düzeylerini yordama gücü. Dicle Üniversitesi Ziya Gökalp Ĕ̈itim Fakültesi Dergisi, 20, 212-229.

Zimmerman, B. J., Bandura, A., \& Martinez-Pons, M. (1992). Self-motivation for academic attainment: The role of self-efficacy beliefs and personel goal setting. American Educational Research Journal, 29, 663-676.

Zimmerman, B. J., \& Risemberg, R. (1997). Become a self-regulated writer: A social cognitive perspective. Contemporary Educational Psychology, 22, 73-101.

\section{Kaynak Gösterme}

Dursun-Sürmeli, Z. ve Ünver, G. (2017). Öz-düzenleyici öğrenme stratejileri, epistemolojik inançlar ve akademik benlik kavramı ile matematik başarısı arasındaki ilişki. Türk Bilgisayar ve Matematik Eğitimi Dergisi, 8(1), 83102.

\section{Citation Information}

Dursun-Sürmeli, Z., \& Ünver, G. (2017). The relationship between mathematics achievement, self-regulated learning strategies, epistemological beliefs and academic self-concept. Turkish Journal of Computer and Mathematics Education, 8(1), 83-102. 